\title{
Analysis and optimization of interactions between peptides mimicking the GD2 ganglioside and the monoclonal antibody 14G2a
}

\author{
IRENA HORWACIK ${ }^{1}$, MATEUSZ KURCIŃSKI ${ }^{3}$, MAŁGORZATA BZOWSKA ${ }^{2}$, ALEKSANDRA K. KOWALCZYK ${ }^{1}$, \\ DOMINIK CZAPLICKI ${ }^{1}$, ANDRZEJ KOLIŃSKI ${ }^{3}$ and HANNA ROKITA ${ }^{1}$ \\ ${ }^{1}$ Laboratory of Molecular Genetics and Virology, ${ }^{2}$ Department of Immunology, Faculty of Biochemistry, \\ Biophysics and Biotechnology, Jagiellonian University, 30-387 Krakow; ${ }^{3}$ Laboratory of Theory \\ of Biopolymers, Faculty of Chemistry, University of Warsaw, 02-093 Warsaw, Poland
}

Received December 23, 2010; Accepted February 15, 2011

DOI: $10.3892 / \mathrm{ijmm} .2011 .655$

\begin{abstract}
Overexpression of the GD2 ganglioside (GD2) is a hallmark of neuroblastoma. The antigen is used in neuroblastoma diagnosis and to target newly developed therapies to cancer cells. Peptide mimetics are novel approaches in the design of antigens for vaccine development. We previously reported the isolation of five GD2-mimicking peptides from the LX-8 phage display library with the monoclonal antibody (mAb) 14G2a. The goal of our current study was to analyze and optimize the binding of the peptide mimetics to the $\mathrm{mAb} 14 \mathrm{G} 2 \mathrm{a}$. Therefore, we performed further experiments and supported them with molecular modeling to investigate structure-activity relationships that are the basis for the observed mimicry of GD2 by our peptides. Here, we show that the peptides have overlapping binding sites on the $\mathrm{mAb}$, 14G2a and restricted specificity, as they did not crossreact with other ganglioside-specific antibodies tested. In addition we demonstrate that the phage environment was involved in the process of selection of our peptides. The AAEGD sequence taken from the viral major coat protein, $\mathrm{p} 8$, and added to the C-termini of the peptides \#65, \#85 and \#94 significantly improved their binding to the mAb, 14G2a. By application of analogs with amino acid substitutions and sequence truncations, we elucidated the structure-activity relationships necessary for the interactions between the 14G2a $\mathrm{mAb}$ and the peptide \#94 (RCNPNMEPPRCF). We identified amino acids indispensable for the observed GD2-mimicry by \#94 and confirmed a pivotal role of the disulphide bridge between the cysteine residues of \#94 for binding to the mAb
\end{abstract}

Correspondence to: Dr Irena Horwacik, Laboratory of Molecular Genetics and Virology, Faculty of Biochemistry, Biophysics and Biotechnology, Jagiellonian University, 7 Gronostajowa St., 30-387 Krakow, Poland

E-mail: irena.horwacik@uj.edu.pl

Key words: cancer, carbohydrate mimicking peptide, neuroblastoma, GD2 ganglioside
14G2a. More importantly, we report five new peptides demonstrating a significant improvement of mAb 14G2a binding. The experimental data were supported and expanded with molecular modeling tools. Taken together, the experimental results and the in silico data allowed us to probe in detail the mechanism of the molecular mimicry of GD2 by the peptides. Additionally, we significantly optimized binding of the leading peptide sequence \#94 to the mAb 14G2a. We can conclude that our findings add to the knowledge on factors governing selections of peptide mimetics from phage-display libraries.

\section{Introduction}

Peptide libraries based on bacteriophage expression are pivotal tools to study the biomolecular interactions and are proved sources of novel ligands with potential therapeutic or biotechnological value (1). Prominent examples are surrogate antigens of both protein and non-protein molecules identified with antibodies. Such mimetic peptides can be applied in situations where the use of a native ligand may not be best suited $(2,3)$. Isolation of mimetics is based on a phenomenon of molecular mimicry and is attributed to the conformational similarity between two or more otherwise chemically diverse molecules.

An important group of peptide mimetics consists of peptides developed for immunotherapy approaches to provide alternative antigens to replace glycans in vaccine formulations. Carbohydrates are relevant medical targets, because they are major constituents of the cell wall of bacterial or fungal pathogens, and antigens well-known for their aberrant expression in cancer. However, they are often poorly or non-immunogenic in infants, children, and immunocompromised individuals $(4,5)$. Correlations between antigenic and immunogenic properties of carbohydrate-mimicking peptides have been investigated to show that peptide surrogates can successfully replace carbohydrate antigens (6-8). Additionally, the relative ease to manufacture and modify peptides should be highlighted, in contrast to the often challenging and costly synthesis of carbohydrates. 
The GD2 ganglioside is an important example of a tumorassociated carbohydrate antigen. It is highly overexpressed in cancer cells of a childhood tumor, neuroblastoma, but also in other malignancies such as melanoma, sarcoma, or small cell lung carcinoma (9-11). GD2 is a glycolipid, consisting of an outer carbohydrate part, charged by the presence of two sialic acid residues, and a membrane anchor formed by a ceramide (fatty acid sphingosine).

Several GD2-binding mAbs have been developed $(12,13)$. Such antibodies are currently used for the diagnosis and monitoring of treatment response in neuroblastoma patients. In clinical trials, anti-GD2 monoclonal antibody-based therapy of neuroblastoma patients was shown to be effective, and it is currently further refined to improve poor survival of patients with high risk disease $(14,15)$. In addition to passive approaches, immunization strategies targeting GD2 are under development. One of the approaches tested is the active immunization with surrogates of GD2, which are exploited to improve the immunogenicity of GD2. They include antiidiotypic antibodies $(16,17)$ and peptide mimotopes $(18,19)$. In practice, application of such surrogate antigens is often preceded by analysis of the molecular basis of mimicry, which then enables optimization of the leading sequence.

Recently, we have described a series of 12-amino acid constrained peptides capable of binding the anti-GD2 mAb, $14 \mathrm{G} 2 \mathrm{a}$, isolated from the LX-8 phage-displayed peptide library (20). The mAb, 14G2a, can effectively mediate in vitro and in vivo cytotoxicity against neuroblastoma cells (21) and has a well-established record of medical applications $(22,23)$. The peptide sequences isolated by us with the mAb 14G2a can be grouped in two clusters: one consisting of the sequences \#85, \#D, \#8, and the second including \#65, \#94 sequences (Table I). In competition tests against human neuroblastoma IMR-32 cells, which abundantly express the GD2 ganglioside, all peptides were shown to mimic the tumor-associated carbohydrate antigen.

The goal of our current study was to optimize the binding of the peptide mimetics to the mAb 14G2a. Therefore, we performed further in vitro experiments and supported them with molecular modeling to investigate the structure-activity relationships that are the basis for the observed mimicry of GD2 by the peptides. Here, as a result, we report five new peptide sequences with significantly improved binding to the mAb 14G2a. Additionally, we determined reactivity of the peptides with other ganglioside-specific antibodies and demonstrate that the peptides have overlapping binding sites on the mAb 14G2a. By design and analysis in the competition tests of several peptide analogs with amino acid substitutions, sequence truncations, and extensions we probed in detail the molecular mechanism of the GD2 mimicry observed for one of our peptides (\#94).

\section{Materials and methods}

Cell lines, antibodies, gangliosides. IMR-32 (a GD2-positive human neuroblastoma cell line) (10) was purchased from ATCC (LCG Standards, Lomianki, Poland). The IMR-32 cells were grown in E-MEM supplemented with non-essential amino acids $(1 \%)$, sodium pyruvate $(1 \mathrm{mM})$, gentamicin (50 mg/l), 10\% fetal bovine serum (FBS) (complete medium
E-MEM). Murine mAb 14G2a (IgG2a), recognizing the GD2 ganglioside was produced by a hybridoma cell line that was a gift from Dr R.A. Reisfeld (The Scripps Institute, La Jolla, CA, USA). Hybridomas producing mouse mAbs recognizing GD2, i.e., mAb ME361-S2a (IgG2a) and mAb 126 (IgM) were purchased from ATCC. All hybridomas were grown in DMEM (with a glucose concentration of $4.5 \mathrm{~g} / \mathrm{l}$ ) supplemented with gentamicin $(50 \mathrm{mg} / \mathrm{l})$ and $10 \%$ FBS (complete DMEM). The cell lines were cultured at $37^{\circ} \mathrm{C}$ in a humidified $5 \% \mathrm{CO}_{2}$ incubator. The cell culture reagents were purchased from Sigma-Aldrich (St. Louis, MO, USA). Other antibodies used in the study included: the GD3 ganglioside (GD3) binding mouse mAb ME3.6 (IgG3) (BD Biosciences Pharmingen, San Diego, CA, USA); the horseradish peroxidase (HRP)conjugated, anti-p8 mouse mAb (Amersham Biosciences, Uppsala, Sweden); the fluorescein-5-isothiocyanate (FITC)conjugated goat affinity purified $\mathrm{F}\left(\mathrm{ab}^{\prime}\right)_{2}$ fragments to mouse immunoglobulins IgA, IgG, IgM (Cappel, MP Biomedicals, Aurora, OH, USA); and the HRP-conjugated anti-mouse IgG (whole molecule) rabbit antibodies (Sigma-Aldrich). The gangliosides used in the study included: GD2 from human brain and GD3 from bovine butter milk (both form Calbiochem, Merck Chemicals Ltd., Nottingham, UK).

Peptides. Peptide sequences of GD2 mimetics (\#8, \#65, \#85, \#94, \#D) expressed on phages and \#0-phage (a phage without any fusion peptide) were isolated during biopanning of the LX-8 library with mAb 14G2a [for a detailed description of the biopanning and the preparation of the phage-expressed peptides see Horwacik et al (20)]. The major coat protein $\mathrm{p} 8$ is used for peptide display in the LX-8 library (24). Peptides were synthesized by GenScript USA Inc. (Piscataway, NJ, USA) and Sigma-Aldrich. The peptides were delivered in a lyophilized form at a purity of $\sim 90 \%$. To dissolve the lyophilized peptides, first N,N-dimethylformamide (Fluka) was added to each peptide sample, then diluted with water to a peptide concentration of 20 or $10 \mathrm{mM}$.

Production, purification, and modification of the $m A b$. The cell culture media (serum-free) containing monoclonal antibodies were sterile filtered through $0.45 \mu \mathrm{m}$ syringe filters to remove any particulates. Two mouse $\operatorname{IgG} 2 \mathrm{a}$ antibodies, the $\mathrm{mAb}, 14 \mathrm{G} 2 \mathrm{a}$, and the mAb, ME361-S2a, were purified with HiTrap protein $\mathrm{G}$ columns (Amersham Biosciences) according to the manufacturer's protocol. For mAb 126, a column with a protein $\mathrm{L}$ resin was used (Pierce, Thermo Scientific). The antibodies bound to the columns were eluted with $0.1 \mathrm{M}$ glycine- $\mathrm{HCl}$ buffer ( $\mathrm{pH} 2.7$ ), and neutralized with $1 \mathrm{M}$ Tris- $\mathrm{HCl}$ (pH 9.0). The fractions containing the antibodies were dialyzed against a final volume of 4 liters of phosphate buffered saline

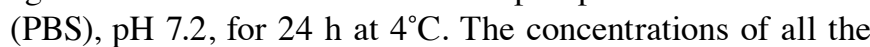
purified antibodies were determined with the Bicinchoninic assay (Sigma-Aldrich) using bovine serum albumin (BSA) as a standard (Sigma-Aldrich). The purity of the antbodies was verified using SDS-PAGE. Biotinylation of mAb 14G2a was performed with sulfo-NHS-LC biotin (Sigma-Aldrich) (25).

Flow cytometry analyses of the free peptides binding to $m A b$, $14 G 2 \mathrm{a}$. The synthetic peptide mimetics of the GD2 ganglioside, their analogs with the designed sequence modifications, 
and the control \#T2 peptide with the HEDIISLWDQSL sequence derived from the HIV-1 envelope glycoprotein, (26) were incubated overnight at $4^{\circ} \mathrm{C}$ with $200 \mathrm{ng}$ of the $14 \mathrm{G} 2 \mathrm{a} \mathrm{mAb}$ in $2 \% \mathrm{BSA} / \mathrm{PBS}$, (BSA from Amresco Inc., Solon, OH, USA). To determine the binding of the peptides to $\mathrm{mAb} 14 \mathrm{G} 2 \mathrm{a}$, the peptides were used over a range of concentrations obtained from serial dilutions decreasing by the factor of 2 . The next day, the samples were used in a competition assay with GD2-positive IMR-32 cells for $1 \mathrm{~h}$ at $4^{\circ} \mathrm{C}$. After the washing steps, the binding of mAb $14 \mathrm{G} 2 \mathrm{a}$ was detected with mouse Ig-specific FITC-conjugated goat $\left.\mathrm{F}(\mathrm{ab})_{2}\right)_{2}$ fragments using flow cytometry (BD ${ }^{\mathrm{TM}}$ LSR II with BD FACSDiva software, BD Biosciences). Cells $\left(10^{4}\right.$ per sample) were collected, and the signal from the cells stained with the secondary antibody alone was used to determine the positively stained pools of the IMR-32 cells. In these pools, the mean fluorescence intensity (MFI) and \% of stained cells (\%SC) were measured, and then used for the calculation of the fluorescence index (FLindex) according to the formula: FLindex $=($ MFI x \%SC $) / 100$. Values of the percentage of the inhibition were calculated using the formula: $\%$ inhibition $=\left(1-\right.$ FLindex $_{\text {peptide }} /$ FLindex $\left._{\max }\right) \times 100 \%$, where the FLindex max $_{\max }$ was calculated from samples with the the $\mathrm{mAb} 14 \mathrm{G} 2 \mathrm{a}$, alone. At least three experiments were performed for each of the analyzed sequences. Mean values of three independent experiments were presented on graphs with SEM (standard error of the mean) for the error bars. Statistical significance was verified with independent two sample t-tests with $\mathrm{p} \leq 0.05, \mathrm{p} \leq 0.01, \mathrm{p} \leq 0.001$.

Competitive ELISA. Wells of the high protein binding plates were coated with $1 \mu \mathrm{g}$ of streptavidin (Sigma-Aldrich) in TBS buffer (50 mM Tris-HCl, pH 7.5, $150 \mathrm{mM} \mathrm{NaCl}$ ) overnight at $4^{\circ} \mathrm{C}$. The next day, the wells were washed with TBS, and blocked with $2 \% \mathrm{BSA} / \mathrm{TBS}$ for $1 \mathrm{~h}$ at $37^{\circ} \mathrm{C}$. After 3 washes with $0.1 \%$ Tween-20/TBS, the biotinylated $14 \mathrm{G} 2 \mathrm{a}$ mAb $(0.1 \mu \mathrm{g} /$ well $)$ in $2 \% \mathrm{BSA} / \mathrm{TBS}$ was applied to the wells for $1 \mathrm{~h}$ at room temperature (RT). After 4 washes, the synthetic peptides \#85 and \#94 mimicking GD2 and the control nonbinding peptide, \#T2, all at a $0.3 \mathrm{mM}$ concentration, were mixed with phages expressing peptides \#65, \#85, \#94 $\left(10^{11}\right.$ phage particles per well) for $1.5 \mathrm{~h}$ at RT. Unbound phages were removed with 6 washes with $0.1 \%$ Tween-20/TBS, and then the mAb 14G2a-bound phages were detected with an anti-p8 HRP-conjugated $\mathrm{mAb}$ for $1 \mathrm{~h}$ at RT. After 6 washes with $0.1 \%$ Tween-20/TBS, the TMB substrate reagent set (BD Biosciences Pharmingen) was used to develop the signals. Absorbance values at $450 \mathrm{~nm}$ were collected. Samples were tested in duplicates. Three independent experiments were performed, and results from a representative experiment are presented as mean values $( \pm$ SEM). Statistical significance was verified with independent two t-tests with $\mathrm{p} \leq 0.05, \mathrm{p} \leq 0.01$, $\mathrm{p} \leq 0.001$.

ELISA to detect binding of peptides to ganglioside-specific antibodies other than mAb 14G2a. The peptides \#65, \#94, \#85 expressed on the surface of phages were used in duplicates to coat 96-wells plates (MaxiSorp surface, NUNC A/S, Roskilde, Denmark) in TBS overnight at $4^{\circ} \mathrm{C}$, and then washed 3 times with TBS. Phage \#0 (with no peptide expressed) was used as a negative control in the assay. The next day, the wells were blocked with $2 \% \mathrm{BSA} / \mathrm{TBS}$ for $1 \mathrm{~h}$ at $37^{\circ} \mathrm{C}$ and then washed 4 times with $0.1 \%$ Tween-20/TBS. Incubations with anti-ganglioside antibodies $(0.2 \mu \mathrm{g} /$ well $)$ were carried out for $1 \mathrm{~h}$ at RT, and then the wells were washed 4 times with $0.1 \%$ Tween-20/TBS. The binding of each antibody was detected for $1 \mathrm{~h}$ at RT with the secondary HRP-conjugated anti-mouse IgG antibodies diluted in 2\% BSA/TBS. After the final washes of the wells, signals were developed with TMB Substrate, and then absorbance values at $450 \mathrm{~nm}$ were collected. To prove the specificity of the antibodies used in the assay, additional wells were coated with $50 \mathrm{ng}$ of GD2 or GD3 in ethanol, and then left for the diluent to evaporate. Three independent experiments were performed and the results from a representative experiment are presented as mean values.

Molecular modeling. Interactions between mAb 14G2a and the investigated peptides were modeled in the following procedure. First, template-based modeling was done to obtain a three-dimensional structure of the receptor (14G2a). Blast scanning of the PDB (Protein Data Bank) database against the receptor sequence identified the $1 \mathrm{SVZ}$ structure as a template for comparative modeling. Blast-generated alignment was used. Structure was modeled with CABS, a reduced space molecular modeling tool, which has been described in great detail elsewhere $(27,28)$. Next, the obtained model of the receptor was used in docking simulations of five investigated peptides. Docking was carried out by CABS Dock, a CABSbased tool enhanced with multi-chain protein support. Each of the simulations produced 5,000 models of the receptorpeptide complex, reduced to a $\mathrm{C}-\alpha$ trace representation. These models were subsequently clustered with respect to their mutual similarity measured as root mean square deviation (RMSD) computed on C- $\alpha$ atoms. For each of the peptides, the structure closest to the centroid of the most populated cluster was selected for further processing, which included reconstruction of the C- $\alpha$ only to full-atom models and energy minimization by means of molecular mechanics. These were performed with the SYBYL Amber99 force field with default parameters. Models of the complexes were ranked by the interaction energy between the receptor and five investigated peptides. The same all-atom models were used to identify the interacting amino acid residues.

\section{Results}

The mimicking peptides \#65, \#85 and \#94 share overlapping binding areas on the anti-GD2 $m A b, 14 G 2 \mathrm{a}$. We aimed at choosing one leading peptide sequence for further optimization of $\mathrm{mAb} 14 \mathrm{G} 2 \mathrm{a}$ binding. Therefore, we investigated structure-activity relationships that are necessary for the observed mimicry of GD2. The peptides \#8 and \#D were not included in the assays, due to their high sequence similarity with the peptide \#85 (Table I). Also, in respect to peptide \#D a significantly lower binding to the antibody was observed, which prompted us to exclude the peptide sequence from further analyses. As for peptides \#65, \#85 and \#94 isolated with mAb 14G2a, we examined whether the mimetics share binding areas on the antibody rather than interacting with independent binding sites. We set up a competition ELISA, 
Table I. Amino acid sequences of peptides mimicking the GD2 ganglioside isolated with mAb 14G2a from the LX-8 phagedisplay library.

\begin{tabular}{ll}
\hline Peptide code & Peptide sequence \\
\hline$\# 8$ & NCDLLTGPMLCV \\
$\# 85$ & VCNPLTGALLCS \\
$\# D$ & GCDALSGHLLCS \\
$\# 65$ & SCQSTRMDPNCW \\
$\# 94$ & RCNPNMEPPRCF
\end{tabular}

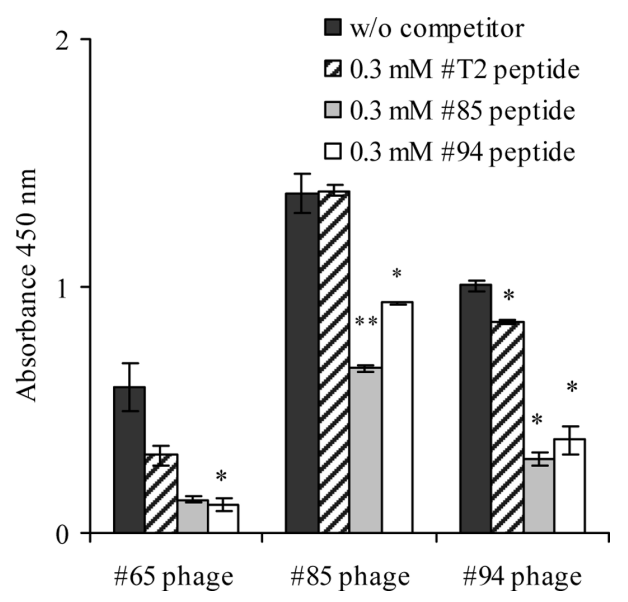

Figure 1. Results of the competitive ELISA. The assay was used to detect binding of \#65, \#85 and \#94 peptides expressed on phages to the biotinylated $\mathrm{mAb} 14 \mathrm{G} 2 \mathrm{a}$, attached to streptavidin-coated wells in the presence of competitors $(0.3 \mathrm{mM})$, i.e., free peptides \#85, \#94 and \#T2. Binding was detected with the HRP-conjugated anti-p8 antibody and signals were developed with the TMB substrate, followed by measurement of the absorbance values at $450 \mathrm{~nm}$. Data from a representative experiment of three separate experiments are shown (samples were tested in duplicates, mean values \pm SEM are shown in the graph); ${ }^{*} \mathrm{p} \leq 0.05,{ }^{* *} \mathrm{p} \leq 0.01$ (two sample independent t-tests).

in which the free peptides \#85 and \#94, and the control $\mathrm{mAb} 14 \mathrm{G} 2 \mathrm{a}$ non-binding peptide \#T2 (all used at a $0.3 \mathrm{mM}$ concentration), were mixed with phages expressing peptides \#65, \#85 or \#94, and were then allowed to compete for binding to the biotinylated-mAb 14G2a molecules attached to streptavidin-coated wells. Next, the viral particles interacting with the immobilized antibody were detected with an anti-p8 protein HRP-conjugated antibody.
Data from a representative inhibition experiment are shown in Fig. 1. Significant reductions of mAb 14G2a binding for the phages expressing the peptides \#65, \#85 and \#94 were observed in the presence of the free GD2-mimetics \#85 or \#94 used as competitors, as compared to the control peptide \#T2. The synthetic peptide \#85 reduced the binding of the \#65 phage to $43 \%$, \#85 phage to $48 \%$ and \#94-phage to $35 \%$ of the signal measured in the presence of the \#T2 peptide. For the synthetic peptide \#94 the calculated values were $36 \%$ for the \#65 phage, $67 \%$ for the \#85 phage and $44 \%$ for the \#94 phage. The effect was tested for two additional concentrations of the synthetic competitors $(0.1$ and $0.5 \mathrm{mM})$, and was observed to be dose-dependent (data not shown). The above data allowed us to conclude that despite clear differences in their amino acid sequences, the peptides \#65, \#94 and \#85 may have overlapping binding sites on the 14G2a antibody molecule.

Peptides \#65, \#85 and \#94 do not crossreact with other ganglioside-specific antibodies tested. Next, we decided to determine whether our peptides can bind to other commercially available GD2 ganglioside-specific monoclonal antibodies by ELISA. In addition to $\mathrm{mAb} 14 \mathrm{G} 2 \mathrm{a}$ (used as a positive control), we tested two other mouse mAb binding to GD2, i.e., $\mathrm{mAb}$ ME361-S2a and $\mathrm{mAb}$ 126. A mouse anti-GD3 mAb (mAb ME3.6) was used as a specificity control. The phages expressing peptides \#65, \#85, \#94 and the control phage \#0 were used to coat wells of high protein binding plates, as the synthetic peptides were unable to efficiently adhere to the surface (data not shown). Additionally, the binding of all tested antibodies was positively verified in wells coated with GD2 or GD3. Results of the ELISA are presented in Table II. The phage expressing the peptides \#65, \#85 and \#94 showed a diverse degree of binding to $\mathrm{mAb} 14 \mathrm{G} 2 \mathrm{a}$ (a feature previously reported). However, we detected no binding of the peptides to any other antibodies than to mAb 14G2a. Also, phage \#0 did not significantly bind to any of the antibodies tested. In a separate set of experiments, we observed that the peptides did not compete with GD2-positive IMR-32 cells for binding to mAb 126 and mAb ME361-S2a (data not shown). The results prompted us to conclude that the isolated peptides are mimicking a unique GD2 ganglioside epitope, as they specifically interact only with the paratope of the mAb 14G2a.

Extension of GD2-mimicking peptides with amino acids of the phage coat protein, $p 8$, significantly improves their binding to $m A b$ 14G2a. Aiming to optimize the binding of our

Table II. Cross reactivity of phage-expressed peptides \#65, \#85, \#94 and \#0 phage (a negative control) with ganglioside-specific antibodies measured by ELISA.

\begin{tabular}{lcccccr}
\hline Antibody & \multicolumn{7}{c}{$\mathrm{A}_{450 \mathrm{~nm}}$} \\
\cline { 2 - 7 } & $\# 65$ & $\# 85$ & $\# 94$ & $\# 0$ & GD2 & GD3 \\
\hline Anti-GD2 mAb 14G2a & 1.2 & 2.57 & 1.49 & 0.07 & 3.06 & 0.05 \\
Anti-GD2 mAb 126 & 0.07 & 0.07 & 0.07 & 0.07 & 2.84 & 0.06 \\
Anti-GD2 mAb ME361-S2a & 0.09 & 0.09 & 0.09 & 0.09 & 1.576 & 0.09 \\
Anti-GD3 mAb ME3.6 & 0.06 & 0.06 & 0.05 & 0.07 & 0.04 & 0.38 \\
\hline
\end{tabular}



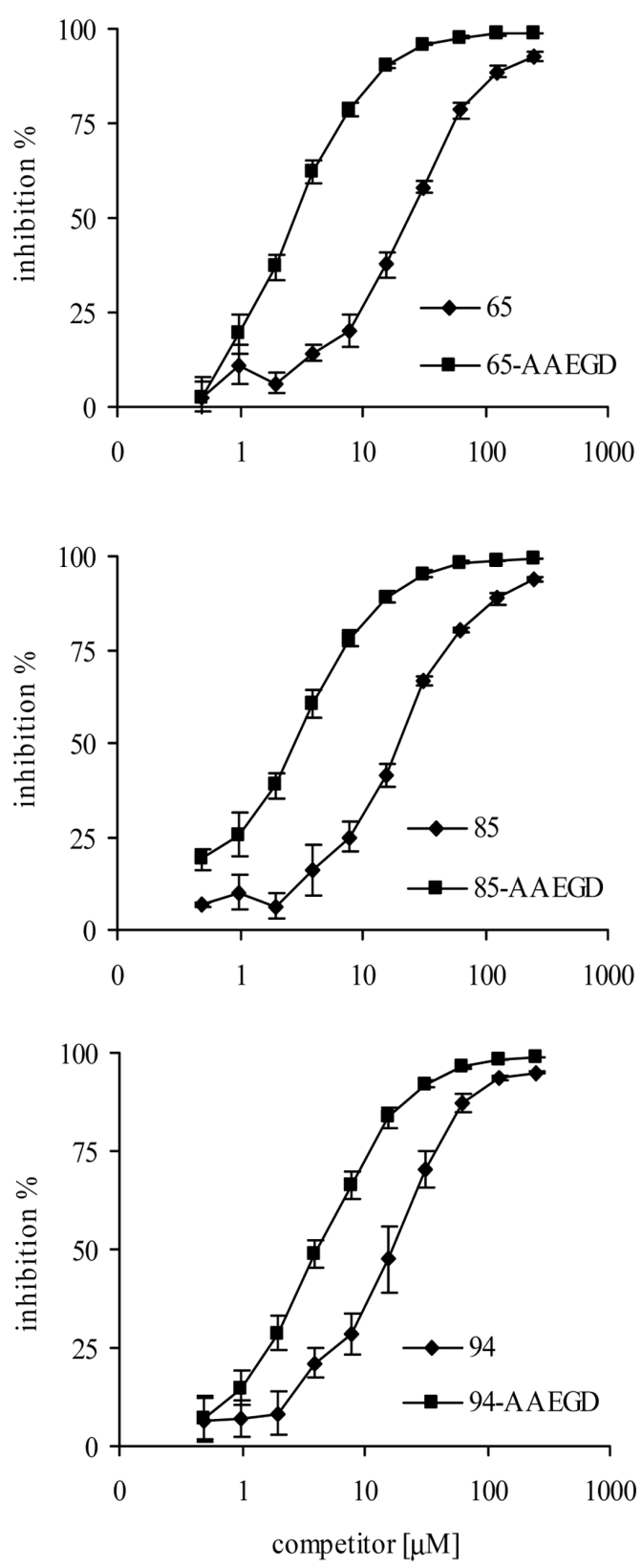

Figure 2. The results from competition experiments with \#65, \#85 and \#94 and their modifications \#65-AAEGD, \#85-AAEGD, \#94-AAEGD. Changes in $\mathrm{mAb} 14 \mathrm{G} 2 \mathrm{a}$ binding after introduction of replacements were tested in the competition assay against the IMR-32 cells for the peptide concentration range of 0.49-250 $\mu \mathrm{M}$ using flow cytometry. Mean values \pm SEM from four independent experiment are shown. peptides to mAb $14 \mathrm{G} 2 \mathrm{a}$, we performed experiments to verify if the phage environment can influence their interaction with $\mathrm{mAb} 14 \mathrm{G} 2 \mathrm{a}$. Our hypothesis was supported by the observation that the first four or five N-terminal amino acids of the $\mathrm{p} 8$ are flexible, in the otherwise rigid structure formed by the interacting p8 monomers of the viral capsid (29). Therefore, we synthesized extended peptides by addition of the AAEGD sequence from the $\mathrm{p} 8$ protein used for display to the C-termini of the peptides \#65, \#85 and \#94.

The results of the performed competition experiments against the GD2 positive IMR-32 neuroblastoma cells for both the initial and the extended peptides are presented in Fig. 2. For all the modified peptides a significant increase in binding to $\mathrm{mAb} 14 \mathrm{G} 2 \mathrm{a}$ was measured as compared to the initially identified sequences. $\mathrm{IC}_{50}$ values (half maximal inhibitory concentration) for all 6 peptides tested are summarized in Table III. The $\mathrm{IC}_{50}$ value of the \#65-AAEGD decreased 8-fold $(\mathrm{p} \leq 0.01)$ as compared to \#65. Similarly, the $\mathrm{IC}_{50}$ value of the \#85-AAEGD decreased 7-fold ( $\mathrm{p} \leq 0.001)$ as compared to \#85. Finally, a nearly 4-fold drop in the $\mathrm{IC}_{50}$ value was calculated for the \#94-AAEGD in comparison to the initial \#94 peptide $(p \leq 0.05)$. The results allowed us to conclude that during the process of isolation of our peptides from the LX-8 phagedisplay library the presence of the viral $\mathrm{p} 8$ protein to some extent influenced the interaction between the peptides and the $\mathrm{mAb} 14 \mathrm{G} 2 \mathrm{a}$.

Alanine scanning of the GD2-mimicking peptide \#94 allows identification of the structural basis necessary for the $m A b$ 14G2a binding. Based on the experiments described above, we chose peptide \#94 as the leading sequence for further analyses and optimization. In the next step, we performed site-specific mutagenesis of the initial 12-amino acid sequences of the \#94 peptide by replacing its consecutive side chains with a small alanine. We evaluated the obtained analogs in competition assays for binding to the mAb 14G2a against GD2 in IMR-32 cells. The results from a representative experiment are shown in Fig. 3. For all except one of the alanine-substituted peptides, a significant decrease in the 14G2a-binding properties was observed in the assay. The substitutions with alanine of C-2, N-3, M-6, E-7, C-11 in the chain of the \#94 peptide resulted in complete loss of binding to $\mathrm{mAb} 14 \mathrm{G} 2 \mathrm{a}$. The $\mathrm{IC}_{50}$ values could not be calculated for the analogs. This indicates their particularly critical role in

Table III. Results of extension experiments with the AAEGD sequence.

\begin{tabular}{llr}
\hline Peptide code & \multicolumn{1}{c}{ Peptide sequence $^{\mathrm{a}}$} & $\mathrm{IC}_{50}(\mu \mathrm{M})^{\mathrm{b}}$ \\
\hline \#65 & SCQSTRMDPNCW & $25.0 \pm 2.2$ \\
$\# 65$-AAEGD & SCQSTRMDPNCWEAEGD & $3.0 \pm 0.2$ \\
$\# 85$ & VCNPLTGALLCS & $20.4 \pm 1.6$ \\
$\# 85$-AAEGD & VCNPLTGALLCSAAEGD & $3.1 \pm 0.3$ \\
$\# 94$ & RCNPNMEPPRCF & $17.1 \pm 2.8$ \\
\#94-AAEGD & RCNPNMEPPRCFAAEGD & $4.7 \pm 0.5$ \\
\hline
\end{tabular}

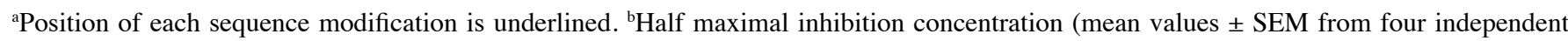
experiments). 


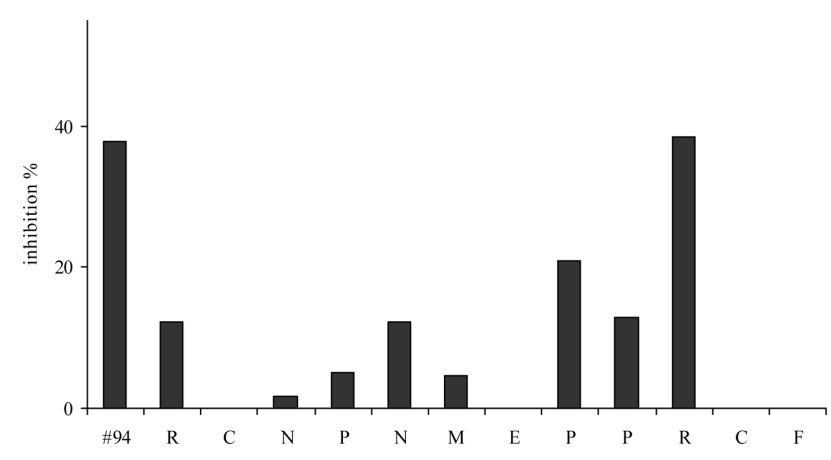

Figure 3. Identification of residues of the peptide \#94 critical for the $\mathrm{mAb} 14 \mathrm{G} 2 \mathrm{a}$ binding by alanine scanning. Changes in mAb 14G2a binding after introduction of alanine in place of the subsequent amino acid were tested in the competition assay against the IMR-32 cells using flow cytometry. Data for the $15.6 \mu \mathrm{M}$ concentration of peptides are shown (for a representative of three separate experiments).

in interaction with mAb 14G2a. For the substitution of the $\mathrm{P}-4$ and $\mathrm{F}-12$ residues with alanine the values of $\mathrm{IC}_{50}$ were calculated, respectively, as 150.8 and $151.2 \mu \mathrm{M}$, while in the experiment the $\mathrm{IC}_{50}$ for \#94 was $20.7 \mu \mathrm{M}$. Moreover, when $\mathrm{R}-1, \mathrm{~N}-5, \mathrm{P}-8, \mathrm{P}-9$ were replaced with alanine the $\mathrm{IC}_{50}$ values were calculated from 45.4 to $56.8 \mu \mathrm{M}$. Only for the peptide in which R-10 was replaced by alanine we did not observe significant changes in the 14G2a-binding properties.

Substitutions introduced into the \#94 peptide allowed identification of a new sequence with higher binding to $m A b$ 14G2a. We further extended our replacement analysis based on the findings from the alanine scanning. We designed and analyzed additional analogs of the \#94 sequence to explore the importance of key side-chain groups, i.e., N-3, M-6, E-7, F-12 and their respective length, hydrophobic or hydrophilic properties on the binding to $\mathrm{mAb} 14 \mathrm{G} 2 \mathrm{a}$. We substituted N-3 with Q or D, M-6 with L or F, E-7 with D, Q or N, and finally F-12 with 2 other natural aromatic amino acids, i.e., W or Y. Results of the competition assay for binding to mAb 14G2a, between such mutated peptides and GD2 expressed in IMR-32 cells, are shown in Fig. 4, and in Table IV. For both N-3 and E-7 all tested replacements in the initial \#94 peptide chain resulted in a complete loss of the binding to $\mathrm{mAb} 14 \mathrm{G} 2 \mathrm{a}$
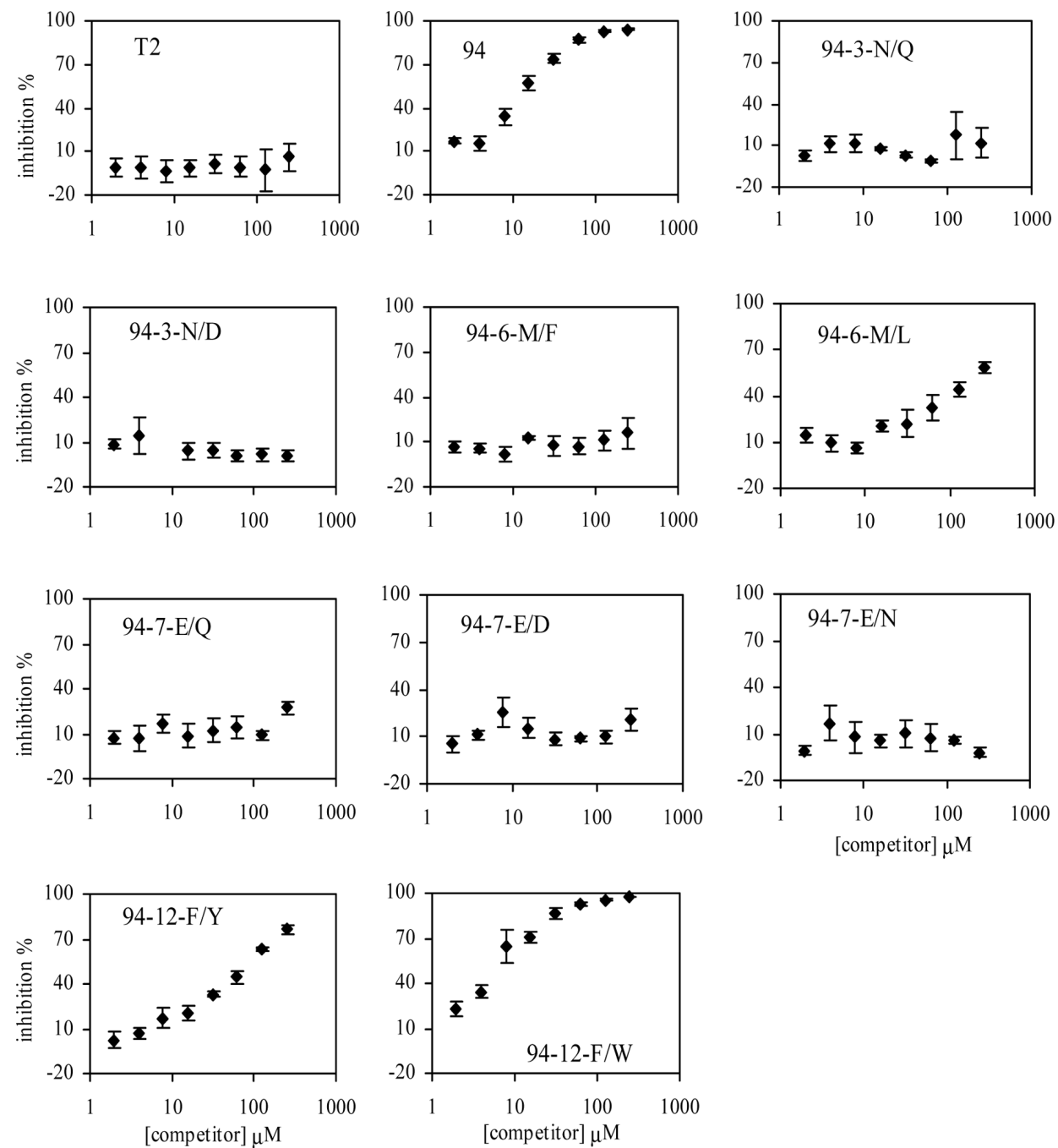

Figure 4. The results from competition experiments with \#94, \#T2 (a negative control) and \#94 analogs containing substitutions of N-3 (N with Q or D), M-6, (M with L or F) E-7 (E with Q, D or N) and F-12 (F with Y or W). Changes in mAb 14G2a binding after introduction of replacements were tested in the competition assay against the IMR-32 cells for peptide concentrations from 1.95-250 $\mu \mathrm{M}$ using flow cytometry (the graphs with \#94 and \#T2 peptides were included for comparison). Mean values \pm SEM from three independent experiments are shown. 
Table IV. Results of substitution, truncation and elongation experiments within the \#94 sequence.

\begin{tabular}{|c|c|c|}
\hline Peptide code & Peptide sequence ${ }^{a}$ & $\mathrm{IC}_{50}(\mu \mathrm{M})^{\mathrm{b}}$ \\
\hline \#T2 & HEDIISLWDQSL & ni \\
\hline \#94 & RCNPNMEPPRCF & $14.0 \pm 2.2$ \\
\hline \#94-3-N/Q & RCQPNMEPPRCF & ni \\
\hline \#94-3-N/D & RCDPNMEPPRCF & ni \\
\hline \#94-6-M/F & RCNPNFEPPRCF & $\mathrm{ni}$ \\
\hline \#94-6-M/L & RCNPNLEPPRCF & $136.4 \pm 33.5$ \\
\hline \#94-7-E/Q & RCNPNMQPPRCF & ni \\
\hline \#94-7-E/D & RCNPNMDPPRCF & ni \\
\hline \#94-7-E/N & RCNPNMNPPRCF & ni \\
\hline \#94-12-F/Y & RCNPNMEPPRC $\underline{Y}$ & $65.0 \pm 3.7$ \\
\hline \#94-12-F/W & RCNPNMEPPRC $\underline{\mathrm{W}}$ & $6.8 \pm 0.4$ \\
\hline$\# 94-\Delta-1$ & --NPNMEP---- & $\mathrm{ni}$ \\
\hline$\# 94-\Delta-2$ & --NPNMEPPR-- & ni \\
\hline$\# 94-\Delta-3$ & -CNPNMEPPRCF & ni \\
\hline$\# 94-\Delta-4$ & RCNPNMEPP-CF & $115.9 \pm 16.8$ \\
\hline \#94-12-F/W-AAEGD & RCNPNMEPPRCWAAEGD & $0.8 \pm 0.1$ \\
\hline
\end{tabular}

${ }^{a}$ The position of each mutation is underlined. ${ }^{b}$ Mean values \pm SEM from three independent experiments are shown. ni, no inhibition measured within the tested range of dilutions of the peptides.

and no $\mathrm{IC}_{50}$ values were observed. Likewise, the \#94-6-M/F surrogate did not bind to the antibody. On the other hand, the replacement of M-6 with L did not completely abrogate binding of the peptide to mAb $14 \mathrm{G} 2 \mathrm{a}$, although a significant 10 -fold rise in the mean $\mathrm{IC}_{50}$ value was observed for the peptide $\left(\mathrm{IC}_{50}=136.4 \pm 33.5 \mu \mathrm{M}, \mathrm{p} \leq 0.05\right)$.

The analysis of the \#94-12-F/Y sequence also showed a significant decrease of binding affinity to mAb 14G2a of the peptide with the introduced hydroxyl group to the aromatic chain with Y (a nearly 5-fold increase in the $\mathrm{IC}_{50}$ value was observed for the peptide, $\left.\mathrm{IC}_{50}=65.0 \pm 3.7 \mu \mathrm{M}, \mathrm{p} \leq 0.001\right)$. On the contrary, for \#94-12-F/W, the peptide with a larger aromatic group of $\mathrm{W}$ introduced in the place of $\mathrm{F}$, the new $\mathrm{IC}_{50}$ value was calculated to be $6.8 \pm 0.4 \mu \mathrm{M}, 2$-fold lower than for peptide \#94 ( $\mathrm{p} \leq 0.05)$.

Truncations of peptide \#94 can significantly change binding to $m A b 14 G 2 \mathrm{a}$ and confirm the pivotal role of the disulphide bridge in the interaction. To find smaller fragments of the \#94 sequence that would bind to mAb 14G2a four shorter peptides derived from \#94 were analyzed. They included two linear peptide sequences NPNMEP (6-amino acid long, \#94- 1 ) and NPNMEPPR (8-amino acid long, \#94- $\Delta 2$ ), as well as two 11-amino acid long peptides missing, respectively, R-1 (\#94- $\Delta 3$ ) and R-10 (\#94- $\Delta 4)$. The results of the competition experiments are shown in Fig. 5. Both peptides lacking the flanking residues including the two $\mathrm{C}$ residues at positions 2 and 11 (NPNMEP and NPNMEPPR) did not bind to the receptor at all, despite the fact that the sequences still contained some of the amino acids pivotal for binding mAb 14G2a (Table IV). The results emphasize the importance of the disulphide bridge-forming cysteines in the observed binding process and confirm the alanine scanning data. Also, deletion of the $\mathrm{R}$ residue at position 1 (\#94- $\Delta 3$ ) resulted in loss of binding to mAb $14 \mathrm{G} 2 \mathrm{a}$, throughout the entire range of concentrations tested. However, the peptide with the eliminated $\mathrm{R}$ at position 10 (\#94- $\Delta 4$ ) could still bind to $\mathrm{mAb} 14 \mathrm{G} 2 \mathrm{a}$, even though a significant reduction of binding was observed (an 8-fold increase in $\mathrm{IC}_{50}$ was measured, $\mathrm{IC}_{50}=115.9 \pm 16.8 \mu \mathrm{M}, \mathrm{p} \leq 0.05$, Table IV).

Peptide analog \#94 combining the 12-F/W substitution with the C-terminal AAEGD-extension shows further improvement of $m A b 14 G 2 \mathrm{a}$ binding. We demonstrated that the addition of the five amino acids of the $\mathrm{p} 8$ protein at the C-terminus of \#94 improved mAb 14G2a-binding (Table III). Therefore, we evaluated one additional peptide (\#94-12-F/W-AAEGD) containing both the 12-F/W substitution and the C-terminal AAEGD-extension and compared it to the initial \#94 and the \#94-AAEGD sequences. We observed a significant improvement of mAb 14G2a binding of \#94-12-F/W-AAEGD, as compared to \#94 and \#94-AAEGD in the competition experiment (Fig. 6). To calculate the $\mathrm{IC}_{50}$ value for the \#94-12-F/W-AAEGD, we measured the inhibition of \#94-12-F/W-AAEGD within the 1.95-250 $\mu \mathrm{M}$ range of concentrations and compared it to \#94. The value of $\mathrm{IC}_{50}$ was significantly improved for \#94-12-F/W-AAEGD peptides as compared to \#94, and was nearly 18-fold lower than \#94 $\left(\mathrm{IC}_{50}=0.8 \pm 0.1 \mu \mathrm{M}, \mathrm{p} \leq 0.01\right.$, Table IV).

Molecular modeling data are in parallel with experimental results. Along with the in vitro experiments, we applied an in silico approach to gather information about structures of the peptide mimetics of GD2 bound to mAb 14G2a (Fig. 7). We calculated the free binding energies for the peptides binding to $\mathrm{mAb} 14 \mathrm{G} 2 \mathrm{a}$. The lowest binding energy was calculated 

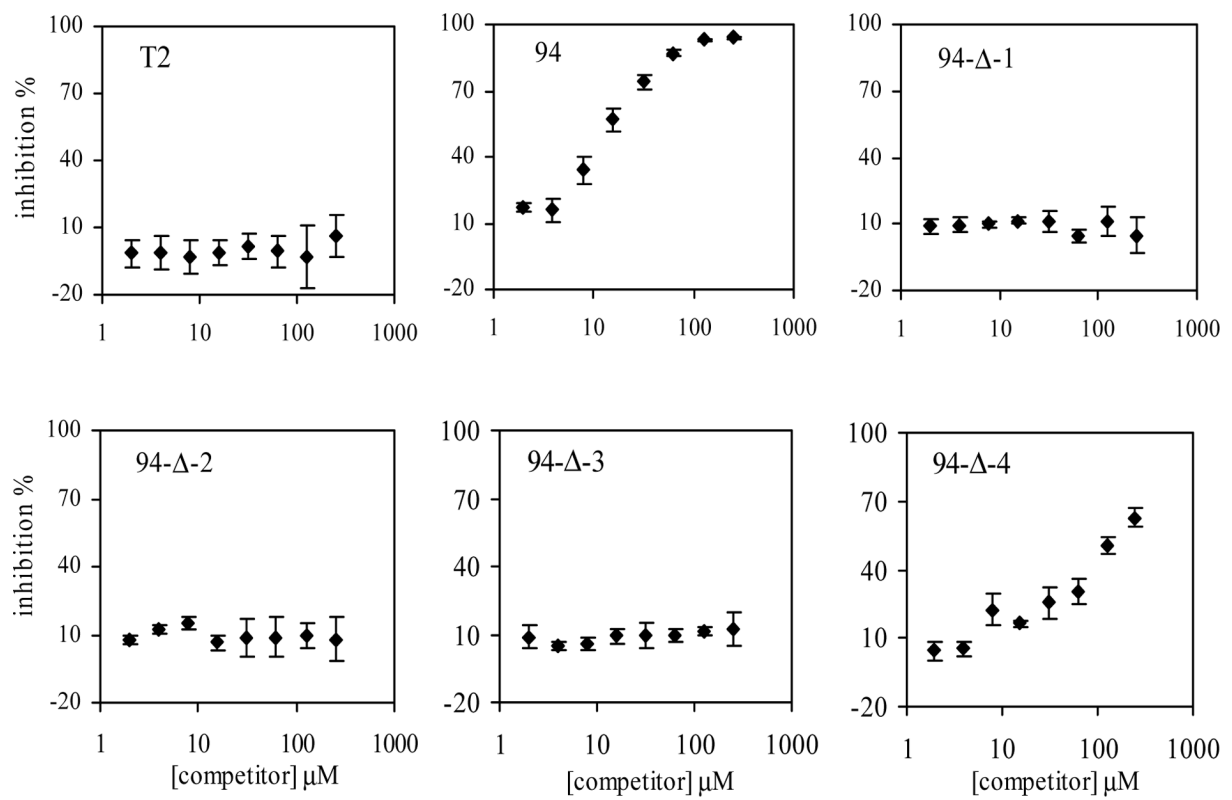

Figure 5. Results from experiments with \#94, \#T2 (a negative control) and \#94 analogs bearing truncations of the peptide sequence. Changes in mAb 14G2a binding after introduction of modifications were tested in the competition assay against IMR-32 cells for peptide concentrations from $1.95-250 \mu \mathrm{M}$ using flow cytometry (the graphs with \#94 and \#T2 peptides were included for comparison). Mean values \pm SEM from three independent experiments are shown.

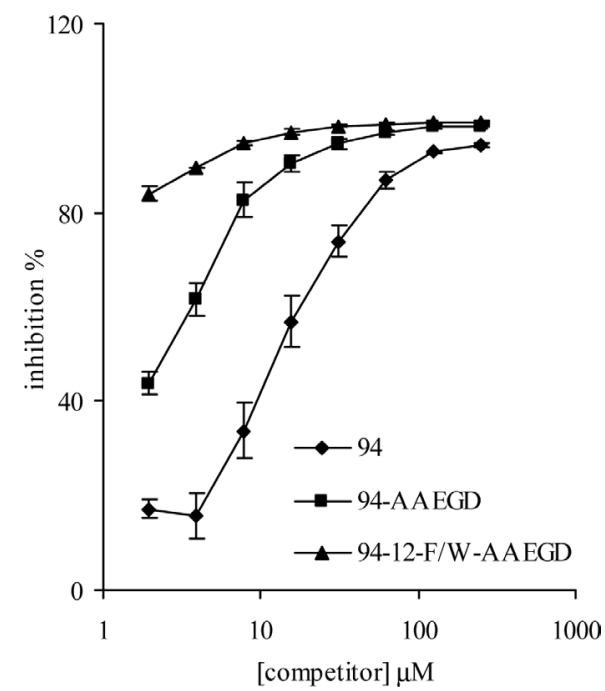

Figure 6. Results from experiments with peptides \#94, \#94-AAEGD and \#94-12-F/W-AAEGD. Changes in mAb 14G2a binding after introduction of the modifications were examined in the competition assay against IMR-32 cells with peptide concentrations from 1.95-250 $\mu \mathrm{M}$ using flow cytometry. Mean values \pm SEM from three independent experiments are shown.

for peptide \#65 $(-228.9 \mathrm{kcal} / \mathrm{mol})$, while the highest was determined for peptide \#D $(-126.7 \mathrm{kcal} / \mathrm{mol})$. For the rest of the peptides the calculated values were comparable, -170.5 , -165.1 and $-178.9 \mathrm{kcal} / \mathrm{mol}$ for \#8, \#85 and \#94, respectively.

Analysis of the molecular model allowed us to identify amino acid residues of peptide \#94 and the mAb 14G2a fragment engaged in the binding. Several close interactions (around $3 \AA ̊$ distance) were identified between the amino acids of peptide \#94 ligands and the mAb 14G2a (Table V). Analysis of the models built for peptides \#8, \#65, \#85, \#94 and \#D and their interactions with the mAb 14G2a fragment support our experimental findings that the peptides share binding areas in the antibody paratope (data not shown). Our studies demonstrated that the computational approach and the experimental methods may successfully complement one another.

\section{Discussion}

Our research stems from the observation that binding of an antigen to its cognate antibody is rarely exclusive, and crossreactivity of immunoglobulin molecules with other epitopes can often be detected (30). We applied this information to isolate peptides mimicking GD2 ganglioside that is one of the antigens used to target neuroblastoma cells. The mimicry phenomenon for peptides isolated from phage-display libraries can be investigated on many levels including phage-expressed and free peptides, or peptides fused to proteins $(31,32)$. Finally, characterization of functional (agonist or antagonist activity) or immunological mimicry of peptides can be performed $(33,34)$. We aimed to probe the molecular basis of mAb 14G2a binding by peptides isolated from the LX-8 library. As a result, we significantly improved binding to mAb 14G2a for the leading sequence (\#94) with application of peptide engineering.

Here, we described several new findings unfolding the molecular basis for the observed interactions between the $\mathrm{mAb}$ 14G2a receptor and the peptide ligands mimicking GD2. Peptides \#65, \#85 and \#94 were shown to occupy overlapping binding areas in the paratope of $\mathrm{mAb} 14 \mathrm{G} 2 \mathrm{a}$. A similar feature was reported for two peptides binding to the gp120 protein of HIV-1 that were isolated from phage-display peptide libraries (35). Our result can also be supported with molecular modeling data showing that peptides \#8, \#65, \#85, \#94 and \#D are in close contact with overlapping amino acids from the modeled mAb 14G2a fragment. In separate experiments, we did not detect any binding of peptides \#65, \#85 and \#94 to two additional GD2-specific antibodies, mAb ME361-S2a and $\mathrm{mAb}$ 126. This may suggest that the isolated peptides 


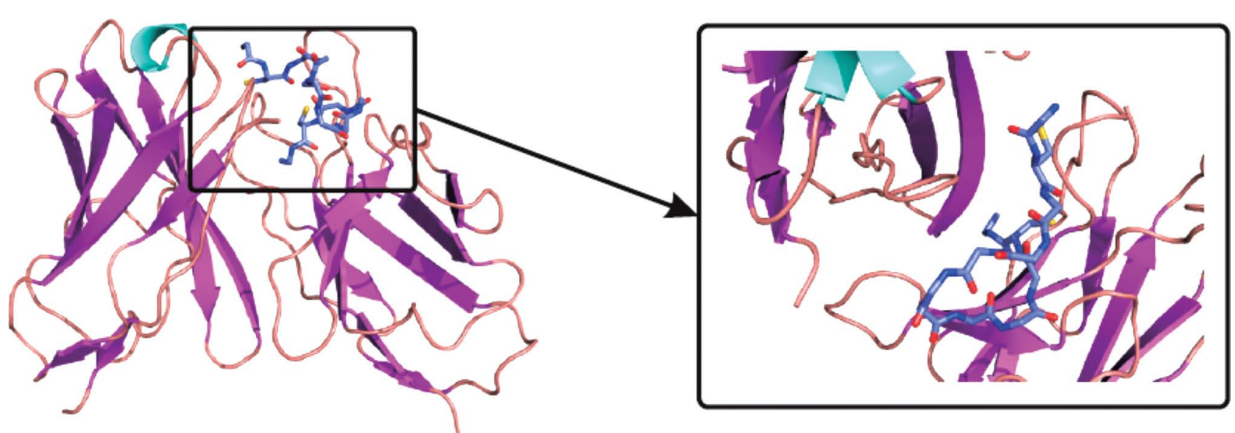

Figure 7. A model of \#94 interaction with a fragment of mAb 14G2a.

Table V. Residues of the receptor (mAb 14G2a) and the ligand molecule (peptide \#94) interacting in the molecular modeling experiments.

\begin{tabular}{llc}
\hline Receptor & Ligand & Distance $(\AA)$ \\
\hline $\mathrm{V}_{\mathrm{L}}: \mathrm{H}-39$ & $\mathrm{R}-10$ & 3.313 \\
$\mathrm{~V}_{\mathrm{L}}: \mathrm{L}-51$ & $\mathrm{R}-10$ & 3.440 \\
$\mathrm{~V}_{\mathrm{L}}: \mathrm{H}-54$ & $\mathrm{P}-8$ & 3.155 \\
$\mathrm{~V}_{\mathrm{L}}: \mathrm{H}-54$ & $\mathrm{R}-10$ & 3.071 \\
$\mathrm{~V}_{\mathrm{L}}:$ P-60 & $\mathrm{R}-10$ & 3.418 \\
$\mathrm{~V}_{\mathrm{H}}: \mathrm{N}-35$ & $\mathrm{R}-1$ & 3.031 \\
$\mathrm{~V}_{\mathrm{H}}: \mathrm{N}-35$ & $\mathrm{C}-2$ & 3.339 \\
$\mathrm{~V}_{\mathrm{H}}: \mathrm{V}-37$ & $\mathrm{R}-1$ & 3.250 \\
$\mathrm{~V}_{\mathrm{H}}: \mathrm{V}-37$ & $\mathrm{~F}-12$ & 3.381 \\
$\mathrm{~V}_{\mathrm{H}}: \mathrm{W}-47$ & $\mathrm{R}-1$ & 2.799 \\
$\mathrm{~V}_{\mathrm{H}}:$ D-52 & N-3 & 2.712 \\
$\mathrm{~V}_{\mathrm{H}}:$ S-59 & N-3 & 2.836 \\
$\mathrm{~V}_{\mathrm{H}}:$ Y-94 & F-12 & 3.465 \\
$\mathrm{~V}_{\mathrm{H}}: \mathrm{V}-96$ & F-12 & 3.254 \\
$\mathrm{~V}_{\mathrm{H}}:$ E-100 & E-7 & 3.157 \\
$\mathrm{~V}_{\mathrm{H}}:$ E-100 & P-9 & 3.495 \\
$\mathrm{~V}_{\mathrm{H}}:$ Y-101 & C-2 & 3.190 \\
$\mathrm{~V}_{\mathrm{H}}:$ Y-101 & E-7 & 3.153 \\
$\mathrm{~V}_{\mathrm{H}}:$ Y-101 & P-9 & 3.113 \\
$\mathrm{~V}_{\mathrm{H}}:$ W-102 & C-11 & 3.040 \\
\hline & &
\end{tabular}

$\mathrm{V}_{\mathrm{L}}$, light chain fragment of the receptor; $\mathrm{V}_{\mathrm{H}}$, heavy chain of the receptor.

mimic a unique GD2 epitope. Another explanation could be that their reactivity patterns are restricted as they are specific only to mAb 14G2a that was used for their isolation from the LX-8 phage-display library. This can further be supported by observations of Harris et al who studied peptides isolated with a panel of mAb binding to a similar epitope of cell wall polysaccharide of group A Staphylococcus. They reported that the peptides bound only to the mAb used for their isolation (36). We can thus conclude that it might be beneficial to isolate peptide mimetics with other GD2-specific antibodies than mAb 14G2a. Combining such peptides mimicking different GD2 epitopes into polyepitope vaccines could broaden the spectrum of induced immune responses against GD2. Peptide mimetics binding to mAb ME361 have been reported (37). Another interesting approach to obtain peptide sequences is the de novo design of mimetics. Tong et al reported recently that peptidic GD2 ligands were rationally designed based on NMR and molecular modeling analyses of GD2 in free form and bound to the anti-GD2 mAb 3F8 (38).

Predicting whether high or low affinity peptides will be isolated from a library seems to be impossible. For peptides mimicking discontinuous epitopes or non-protein antigens, not only the linear sequence, but also the conformation of both the peptide and the binding site on the cognate antibody may play a role, to a various extent, in the isolation process, and later in the reactivity of the peptides $(39,40)$. Additionally, the theoretical diversity of peptide libraries is reduced during their preparation steps and the number of peptide copies expressed on the surface of the viral particles may vary, which in turn affects the results of the screening process (41). Therefore, as a rule the initial leading sequences isolated from phage-display libraries are not the most optimal and require further optimization.

Here, we report five peptide sequences with significantly improved binding to $\mathrm{mAb} 14 \mathrm{G} 2 \mathrm{a}$. Three sequences arose from the C-terminal extension of \#65, \#85 and \#94 with the AAEGD sequence from the $\mathrm{p} 8$ protein used for peptidedisplay. This finding adds to the knowledge on factors driving peptide selections from phage-display libraries. Such positive influence of the viral environment on the binding properties of phage-expressed peptides has also been reported by others $(33,42)$. Therefore, we postulate that addition of amino acids adjacent to expressed peptides can be viewed as a possible mean to improve their interactions with the receptors used in screening of the phage-display libraries.

Two additional improved mimetics were obtained from the application of a systemic approach to analyze in detail the binding of one member of the identified GD2-mimicking peptide set, \#94. We report that both sequence requirements and structure constrains are responsible for the antigenic reactivity with mAb 14G2a. Also, we identified residues critical for the binding. Based on the findings, we substituted F-12 with a larger $\mathrm{W}$ moiety and improved binding of the obtained analog of \#94 to mAb 14G2a. Furthermore, introduction of such a larger aromatic group combined with the AAEGD-extension yielded the best of our peptides. Noteworthy, the tryptophan residue also occupies the last position in the \#65 sequence, stressing that both shared and unique determinants of binding 
of the peptides to $\mathrm{mAb} 14 \mathrm{G} 2 \mathrm{a}$ can be identified. Altogether the data highlight the importance of the C-terminal part of \#94 for the binding.

Finally, we were able to confirm the particularly important role of the disulphide bridge, formed by the $\mathrm{C}$ residue at positions 2 and 11, in the observed binding of the free peptides. The finding was previously reported for all our phage-display peptides based on the observed abrogation of their mAb 14G2a binding in the presence of two agents, dithiothreitol and $\mathrm{N}$-ethylmaleimide, reducing and preventing them from reforming a disulphide bond (20). Altogether, for both the free and the phage-displayed peptides, we can assume that cyclic peptides could adopt or maintain the antigenically reactive structure necessary for GD2 mimicry. In the literature such observations have been reported, e.g., for the EMP1 mimetic of the hormone, erythropoietin, where the presence of a disulphide bridge at positions 6 and 15 was essential in both the 20-amino acid long original EMP1 sequence, as well as in the 13 -amino acid long minimal active sequence. The bridge could not be substituted with an amide bond formed between the introduced side chains of glutamic acid at position 6 and lysine at the position 15 (43). Furthermore, introduction of sequence cyclization to an initially linear peptide was reported to positively modulate antigen reactivity (44).

In conclusion, the described results allowed us to gain a detailed insight into the mode of interaction between our GD2 mimicking peptides and mAb 14G2a. Additionally, we supported the experiments with an in silico approach that yielded data in agreement with in vitro results. Therefore, the methods used to construct the computer model were correct and possibly could be used in further studies on GD2 mimicry. Our findings widen the knowledge about factors governing selections of peptides from phage-display libraries. In the future, we plan to extend our research on the peptides mimicking GD2, as five new and stronger 14G2a-binding peptides were identified. We plan to further analyze the mimetics and correlate the observed antigenicity of the peptides with their possible immunogenicity, as they can be tested as antigens to induce GD2-specific immune responses. We are encouraged to continue research on peptides mimicking GD2, which is a clinically important tumor-associated carbohydrate antigen and a therapeutically relevant target for anticancer treatments.

\section{Acknowledgements}

We are grateful to Dr R.A. Reisfeld for the 14G2a hybridoma cell line. The study was mainly financed in years 2006-2010 from the research grant no. N302 034 31/3063 from the Polish Ministry of Science and Higher Education (to I.H.) and also partially from the Jagiellonian University Grants no. WBBB 8 (to H.R.) and no. BW37/137 (to I.H.).

\section{References}

1. Smith GP and Petrenko VA: Phage display. Chem Rev 97: 391-410, 1997.

2. Beenhouwer DO, May RJ, Valadon P and Scharff MD: High affinity mimotope of the polysaccharide capsule of Cryptococcus neoformans identified from an evolutionary phage peptide library. J Immunol 169: 6992-6999, 2002.
3. Torregrossa P, Buhl L, Bancila M, Durbec P, Schafer C, Schachner M and Rougon G: Selection of poly-alpha 2,8-sialic acid mimotopes from a random phage peptide library and analysis of their bioactivity. J Biol Chem 279: 30707-30714, 2004

4. Fleuridor R, Lyles RH and Pirofski L: Quantitative and qualitative differences in the serum antibody profiles of human immunodeficiency virus-infected persons with and without Cryptococcus neoformans meningitis. J Infect Dis 180: 1526-1535, 1999.

5. Lucas AH, Rittenhouse-Olson K, Kronenberg M, Apicella MA, Wang D, Schreiber JR and Taylor CE: Carbohydrate moieties as vaccine candidates: meeting summary. Vaccine 28: 1121-1131, 2010.

6. Valadon P, Nussbaum G, Oh J and Scharff MD: Aspects of antigen mimicry revealed by immunization with a peptide mimetic of Cryptococcus neoformans polysaccharide. J Immunol 161: 1829-1836, 1998.

7. Cunto-Amesty G, Luo P, Monzavi-Karbassi B, Lees A and Kieber-Emmons T: Exploiting molecular mimicry to broaden the immune response to carbohydrate antigens for vaccine development. Vaccine 19: 2361-2368, 2001.

8. Shin JS, Lin JS, Anderson PW, Insel RA and Nahm MH: Monoclonal antibodies specific for Neisseria meningitidis group $B$ polysaccharide and their peptide mimotopes. Infect Immun 69: 3335-3342, 2001.

9. Yoshida S, Fukumoto S, Kawaguchi H, Sato S, Ueda R and Furukawa K: Ganglioside G(D2) in small cell lung cancer cell lines: enhancement of cell proliferation and mediation of apoptosis. Cancer Res 61: 4244-4252, 2001.

10. Hettmer S, Ladisch S and Kaucic K: Low complex ganglioside expression characterizes human neuroblastoma cell lines. Cancer Lett 225: 141-149, 2005.

11. Ravindranath MH, Muthugounder S and Presser N: Ganglioside signatures of primary and nodal metastatic melanoma cell lines from the same patient. Melanoma Res 18: 47-55, 2008.

12. Cheung NK, Lazarus H, Miraldi FD, Abramowsky CR, Kallick S, Saarinen UM, Spitzer T, Strandjord SE, Coccia PF and Berger NA: Ganglioside GD2 specific monoclonal antibody 3F8: a phase I study in patients with neuroblastoma and malignant melanoma. J Clin Oncol 5: 1430-1440, 1987.

13. Kawashima I, Tada N, Fujimori T and Tai T: Monoclonal antibodies to disialogangliosides: characterization of antibody-mediated cytotoxicity against human melanoma and neuroblastoma cells in vitro. J Biochem 108: 109-115, 1990.

14. Choi BS, Sondel PM, Hank JA, Schalch H, Gan J, King DM, Kendra K, Mahvi D, Lee LY, Kim K and Albertini MR: Phase I trial of combined treatment with ch14.18 and R24 monoclonal antibodies and interleukin-2 for patients with melanoma or sarcoma. Cancer Immunol Immunother 55: 761-774, 2006.

15. Modak S and Cheung NK: Neuroblastoma: therapeutic strategies for a clinical enigma. Cancer Treat Rev 36: 307-317, 2010.

16. Zeytin HE, Tripathi PK, Bhattacharya-Chatterjee M, Foon KA and Chatterjee SK: Construction and characterization of DNA vaccines encoding the single-chain variable fragment of the antiidiotype antibody 1A7 mimicking the tumor-associated antigen disialoganglioside GD2. Cancer Gene Ther 7: 1426-1436, 2000.

17. Basak S, Birebent B, Purev E, Somasundaram R, Maruyama H, Zaloudik J, Swoboda R, Strittmatter W, Li W, Luckenbach A, Song H, Li J, Sproesser K, Guerry D, Nair S, Furukawa K and Herlyn D: Induction of cellular immunity by anti-idiotypic antibodies mimicking GD2 ganglioside. Cancer Immunol Immunother 52: 145-154, 2003.

18. Bolesta E, Kowalczyk A, Wierzbicki A, Rotkiewicz P, Bambach B, Tsao CY, Horwacik I, Kolinski A, Rokita H, Brecher M, Wang X, Ferrone $\mathrm{S}$ and Kozbor D: DNA vaccine expressing the mimotope of GD2 ganglioside induces protective GD2 cross-reactive antibody responses. Cancer Res 65: 3410-3418, 2005.

19. Fest S, Huebener N, Weixler S, Bleeke M, Zeng Y, Strandsby A, Volkmer-Engert R, Landgraf C, Gaedicke G, Riemer AB, Michalsky E, Jaeger IS, Preissner R, Förster-Wald E, JensenJarolim E and Lode HN: Characterization of GD2 peptide mimotope DNA vaccines effective against spontaneous neuroblastoma metastases. Cancer Res 66: 10567-10575, 2006.

20. Horwacik I, Czaplicki D, Talarek K, Kowalczyk A, Bolesta E, Kozbor D and Rokita H: Selection of novel peptide mimics of the GD2 ganglioside from a constrained phage-displayed peptide library. Int J Mol Med 19: 829-839, 2007.

21. Mujoo K, Kipps TJ, Yang HM, Cheresh DA, Wargalla U, Sander DJ and Reisfeld RA: Functional properties and effect on growth suppression of human neuroblastoma tumors by isotype switch variants of monoclonal antiganglioside GD2 antibody 14.18. Cancer Res 49: 2857-2861, 1989. 
22. Lode HN, Handgretinger R, Schuermann U, Seitz G, Klingebiel T, Niethammer D and Beck J: Detection of neuroblastoma cells in $\mathrm{CD} 4^{+}$selected peripheral stem cells using a combination of tyrosine hydroxylase nested RT-PCR and anti-ganglioside GD2 immunocy tochemistry. Eur J Cancer 33: 2024-2030, 1997.

23. Cheung NK, Kushner BH and Kramer K: Monoclonal antibodybased therapy of neuroblastoma. Hematol Oncol Clin North Am 15: 853-866, 2001.

24. Bonnycastle LL, Mehroke JS, Rashed M, Gong X and Scott JK Probing the basis of antibody reactivity with a panel of constrained peptide libraries displayed by filamentous phage. $\mathrm{J}$ Mol Biol 258: 747-762, 1996.

25. Menendez A, Bonnycastle LLC, Pan OCC and Scott JK: Screening peptide libraries. In: Phage Display. A Laboratory Manual. 1st edition. Barbas CF, Burton DR, Scott JK and Silverman GJ (eds.) Cold Spring Harbor Laboratory Press, New York, pp17.8-17.11, 2001.

26. Kröpelin M, Süsal C, Daniel V and Opelz G: Inhibition of HIV-1 rgp120 binding to CD $4^{+} \mathrm{T}$ cells by monoclonal antibodies directed against the gp120 $\mathrm{Cl}$ or $\mathrm{C} 4$ region. Immunol Lett 63: 19-25, 1998.

27. Koliński A: Protein modeling and structure prediction with a reduced representation. Acta Biochim Pol 51: 349-371, 2004.

28. Kurciński M and Koliński A: Steps towards flexible docking: modeling of three-dimensional structures of the nuclear receptors bound with peptide ligands mimicking co-activators sequences. J Steroid Biochem Mol Biol 103: 357-360, 2007.

29. Colnago LA, Valentine KG and Opella SJ: Dynamics of fd coat protein in the bacteriophage. Biochemistry 26: 847-854, 1987.

30. van Regenmortel MH: From absolute to exquisite specificity. Reflections on the fuzzy nature of species, specificity and antigenic sites. J Immunol Methods 216: 37-48, 1998.

31. Zwick MB, Bonnycastle LL, Noren KA, Venturini S, Leong E, Barbas CF III, Noren CJ and Scott JK: The maltose-binding protein as a scaffold for monovalent display of peptides derived from phage libraries. Anal Biochem 264: 87-97, 1998.

32. Popkov M, Sidrac-Ghali S, Alakhov V and Mandeville R: Epitope-specific antibody response to HT-1080 fibrosarcoma cells by mimotope immunization. Clin Cancer Res 6: 3629-3635, 2000.

33. Venkatesh N, Im SH, Balass M, Fuchs S and Katchalski-Katzir E: Prevention of passively transferred experimental autoimmune myasthenia gravis by a phage library-derived cyclic peptide. Proc Natl Acad Sci USA 97: 761-766, 2000.

34. Pameijer CR, Navanjo A, Meechoovet B, Wagner JR, Aguilar B, Wright CL, Chang WC, Brown CE and Jensen MC: Conversion of a tumor-binding peptide identified by phage display to a functional chimeric $\mathrm{T}$ cell antigen receptor. Cancer Gene Ther 14: 91-97, 2007.
35. Ferrer $\mathrm{M}$ and Harrison SC: Peptide ligands to human immunodeficiency virus type 1 gp120 identified from phage display libraries. J Virol 73: 5795-5802, 1999.

36. Harris SL, Craig L, Mehroke JS, Rashed M, Zwick MB, Kenar K, Toone EJ, Greenspan N, Auzanneau FI, Marino-Albernas JR, Pinto BM and Scott JK: Exploring the basis of peptide-carbohydrate crossreactivity: evidence for discrimination by peptides between closely related anti-carbohydrate antibodies. Proc Natl Acad Sci USA 94: 2454-2459, 1997.

37. Wondimu A, Zhang T, Kieber-Emmons T, Gimotty $\mathrm{P}$, Sproesser K, Somasundaram R, Ferrone S, Tsao CY and Herlyn D: Peptides mimicking GD2 ganglioside elicit cellular, humoral and tumor-protective immune responses in mice. Cancer Immunol Immunother 7: 1079-1089, 2008.

38. Tong W, Gagnon M, Sprules T, Gilbert M, Chowdhury S, Meerovitch K, Hansford K, Purisima EO, Blankenship JW, Cheung NK, Gehring K, Lubell WD and Saragovi HU: Smallmolecule ligands of GD2 ganglioside, designed from NMR studies, exhibit induced-fit binding and bioactivity. Chem Biol 17: 183-194, 2010.

39. Ferrières G, Villard S, Pugnière M, Mani JC, Navarro-Teulon I, Rharbaoui F, Laune D, Loret E, Pau B and Granier C: Affinity for the cognate monoclonal antibody of synthetic peptides derived from selection by phage display. Role of sequences flanking the binding motif. Eur J Biochem 267: 1819-1829, 2000.

40. Jung HH, Yi HJ, Lee SK, Lee JY, Jung HJ, Yang ST, Eu YJ, Im SH and Kim JI: Structural analysis of immunotherapeutic peptides for autoimmune Myasthenia gravis. Biochemistry 46: 14987-14995, 2007.

41. Malik P, Terry TD, Gowda LR, Langara A, Petukhov SA, Symmons MF, Welsh LC, Marvin DA and Perham RN: Role of capsid structure and membrane protein processing in determining the size and copy number of peptides displayed on the major coat protein of filamentous bacteriophage. J Mol Biol 260 9-21, 1996.

42. Dorgham K, Dogan I, Bitton N, Parizot C, Cardona V, Debré P, Hartley $\mathrm{O}$ and Gorochov G: Immunogenicity of HIV type 1 gp120 CD4 binding site phage mimotopes. AIDS Res Hum Retroviruses 21: 82-92, 2005.

43. Johnson DL, Farrell FX, Barbone FP, McMahon FJ, Tullai J, Hoey K, Livnah O, Wrighton NC, Middleton SA, Loughney DA, Stura EA, Dower WJ, Mulcahy LS, Wilson IA and Jolliffe LK: Identification of a 13-amino acid peptide mimetic of erythropoietin and description of amino acids critical for the mimetic activity of EMP1. Biochemistry 37: 3699-3710, 1998.

44. Gomes P, Giralt E and Andreu D: Antigenicity modulation upon peptide cyclization: application to the GH loop of foot-and-mouth disease virus strain C1-Barcelona. Vaccine 19: 3459-3466, 2001. 